\title{
Collaborative Inter-firm Relationships Based on Sustainability: Towards a New Framework
}

\author{
Stephane Pagano ${ }^{1}$, Ridha Derrouiche ${ }^{2}$, and Gilles Neubert ${ }^{2}$ \\ ${ }^{1}$ ESC, 51-52 cours Fauriel, BP 29, 42009 Saint Etienne, France \\ stephane_pagano@esc-saint-etienne.fr \\ ${ }^{2}$ ESC - UMR 5600, 53 cours Fauriel, BP 29, 42009 St Etienne, France \\ prenom_nom@esc-saint-etienne.fr
}

\begin{abstract}
After decades of industrial decline, the models of firm competitiveness, green economy, green growth, are making the news. Indeed, there is a growing trend in the reversal of outsourcing or offshoring production of goods and services while inter-firm relationships are under scrutiny. A trend being reinforced by the global awareness on resources scarcity, to integrate in the processes the impacts of climate change and eventually reduce them, to prepare for growing energy costs. The linear economy and it's models of value creation based on trading margins of imported, outsourced, goods and services, global competition between companies, resources spillage, has shown it's limits.
\end{abstract}

Keywords: Value creation, Inter-firm collaboration, responsible supply chain, business models, industry ecosystems.

\section{Introduction}

The twenty-first century started on a profound global crisis affecting the fundamental living supports of human kind: it's social and environmental conditions. Now in the era of anthropocene, human kind has become a geological agent itself that is able to change the very structure of the biosphere, causing the sixth mass extinction of species and posing a global threat to all our global systems with an "economy that extracts resources at increasing rates without consideration for the environment in which it operates, without consideration for our natural planetary boundaries." [1]

Since the Brundtland Commission has given the first definition of sustainable development as a development that "meets the needs of the present without compromising the ability of future generations to meet their own needs" [2], we keep going towards financial crises and natural catastrophes: as the latest report from the World Economic Forum put's it: "Future simultaneous shocks to systems could trigger the 'perfect global storm', with potentially insurmountable consequences" that can doom chances of developing an effective, long-term solution [3]. How did we get there and what can we do to shift the model? 


\section{The State of Our Industries}

An Outdated Model Based on Unsustainability. In a paper published in 2011 in Harvard Business Review, Michael E. Porter and Mark R. Kramer declared: "Capitalism is under siege, business being increasingly viewed as a major cause of social, environmental and economic problems". Indeed, global growing concern for Corporate Social Responsibility speaks for itself.

According to Porter and Kramer, the problem lies in the fact that most companies are trapped in an "outdated model of value creation" which can be summarized in this description: "Facing growing competition and short term performance pressures from shareholders, managers resorted to waves of restructuring, personnel reductions, and relocation to lower-cost regions, while leveraging balance sheets to return capital to investors" [4].

Industrial Decline and Value Creation. Michael Porter and Jan Rivkin asked HBS alumni [5] about where they intended to locate their future business and found that many of them thought wages abroad were lower, and that they needed to reach customers in big new markets, a case to leave or offshore. Though Porter and Rivkin state that firms are now ready to reconsider offshoring, realizing "they overdid it" discovering hidden costs, they argue that "America's government is not making the country's business environment attractive enough for companies to want to come back." One can ask what the government as to do with the responsibility of firms and investors.

A brief look at OECD value added by industry and services, unemployment and commercial balance of goods (figure 1), seems to show some correlation.

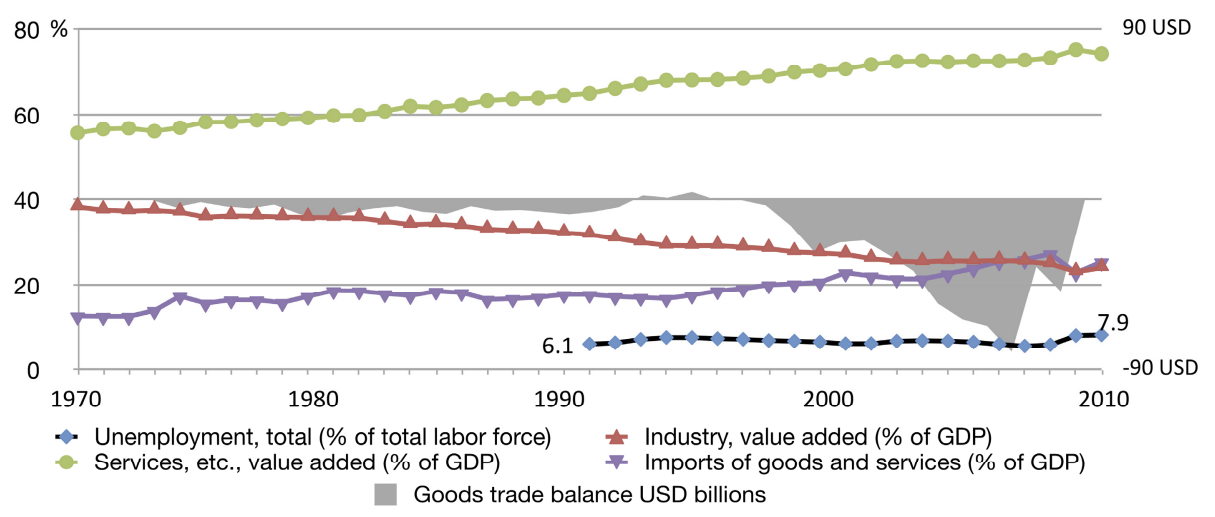

Fig. 1. Evolution of value added by industry and services (source OECD Stats)

The Models Behind the Decline. Michael E. Porter came up with a model that have been at the base of the value creation model he criticizes in 2011:

In 1980, Porter described "Techniques for Analyzing Industries and Competitors" based on "five forces that shape competitive intensity". This model is focused on the environment of the company and comprises three horizontal threats and two vertical 
powers [6]. Horizontal threats are new competitors addressing the market (new entrants), new products that could replace the company's products (substitute products) and the existing rivalry between established companies in the same industry. Vertical powers are on the opposite sides of the value chain of the company: the bargaining power of the suppliers on one side, the bargaining power of the customers on the other side. A model exclusively orientated on confrontation (figure 2).

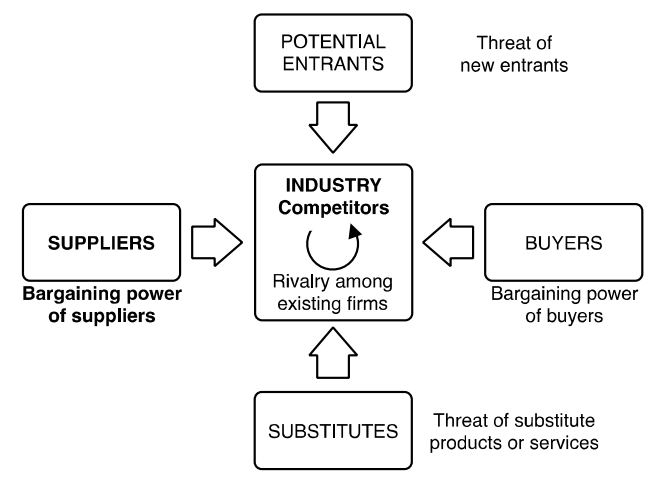

Fig. 2. Porters' five forces that shape competitive intensity

Of course this five forces model is just a part of Porter's strategic model. It has been widely used over the last decades by companies to design their strategies with heavy consequences: in this model, suppliers are exercising a pressure on the company. This vision pushes procurement or buyers to weaken the position of the suppliers [7] by improving the bargaining power of the buyer, for example by using strategies such as "Spread Purchases" (divide to rule) or even manipulate the perception of suppliers to "Create a Threat of Backward Integration: Whether or not the purchaser actually desires to backward integrate into" voluntarily leaking word of internal studies of the feasibility of integration [8]. Is this a justifiable mean for the purpose of gaining power against suppliers? For Porter, "The objective of all these approaches is obviously to lower the total long-run costs of purchasing".

Other strategic models have been studied and advocated in the management of the Supply Chain. In a worldwide opened market, suppliers being available to competitors of the firm, purchasing started to become a strategic function, but most common reference models in dealing with suppliers' portfolio are based on power relations between suppliers and buyers. [9]. Moreover, Porter in 1985, described "Creating and sustaining superior performance" [8] based on two main approaches that can be complementary: competitive strategies based on costs or based on differentiation. In this complimentary book, Porter describes Generic strategies, and the Value chain of the firm, and goes into a finely grained approach of building strategic advantages through extensive cost analysis in the value chain, but also provides a customer approach to "Buyer purchase criteria" that describes the approaches that can be used to create value on differentiation: Use purchase criteria that lower buyer cost or enhance buyer performance, which can comprise product 
quality, features, delivery time etc. Signaling purchase criteria that are based on signals that infer on the perception of the value by the customer, and can include advertising, attractiveness or reputation.

Though since the 70s research literature reflected growing concerns to integrate stakeholders and environmental issues in the business models of firms [10][11][12][13][14], Porters' strategic models kept five types of stakeholders for which the firm creates value based on their power of influence: customers, employees, financial partners, community and shareholders. While shareholders value creation model was gaining momentum, reducing costs and not to mention, neglecting worldwide locations became mainstream. Over the last decades, the evolution of strategic and business models have mainly focused on shareholders value creation and global offshoring and outsourcing [15]. "Overdoing offshoring" is not what we can describe as a discovery.

Regarding industrial decline specifically, the loss of industrial employment was analyzed as not posing a threat for the economies [16] provided it was due to both an increase in productivity in the industries (and a shift to high value industries), improving the population wealth, and, as consequence, a rise of the service economy to absorb the workers, all with the strict provision that the demand for manufactured products wouldn't be satisfied by other industrialized countries. Otherwise, it would lead to a systemic deficit of the balance of payments for countries. We can see that, not only services haven't been able to compensate for industrial jobs losses, but also that the dynamics of the service industry is directly connected to the dynamics of the manufacturing industry, with a ratio connecting both industries [16]. Roughly, there cannot be a service industry without consistent manufacturing industry.

"Improper" outsourcing contributes to the industrial decline of western firms [17]: outsourcing decision can individually make sense and create value, but multiple outsourcing decisions analyzed in the industrial ecosystem reduces the capabilities of a whole industry to remain competitive. Companies get trapped in a "spiral of decline" resulting from defensive incremental outsourcing decisions under the pressure of "underperforming business units to improve cost or profit performance", while corporate executives try to maintain continuous growth in earnings to support stock values, as shown in figure 3 :

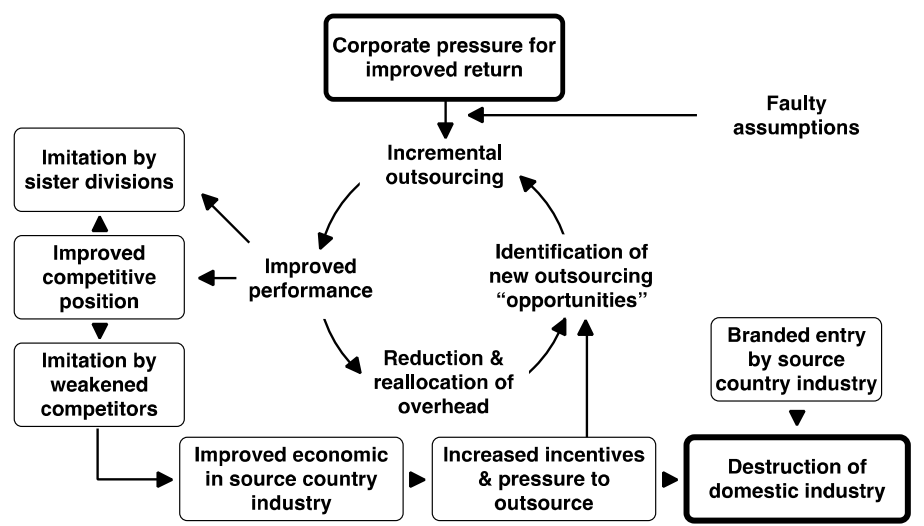

Fig. 3. Spiral of decline of the U.S. and western industries described by Bettis and al 
After decades of this industrial decline, the models of firm competitiveness, green economy, green growth and reindustrialization, are making the news. Indeed, there is a growing trend in the reversal of outsourcing or offshoring production of goods and services while inter-firm relationships are under scrutiny.

This trend is being reinforced by the global awareness on resources scarcity, the necessity to protect high value research and development, to integrate in the processes the impacts of climate change and eventually reduce them, to prepare for ever growing energy costs. The business models based on high margin trading on imported, outsourced, goods and services, and global competition between companies and even territories, without sound rules, seem to have shown their limits.

\section{$3 \quad$ Measuring the Losses to Rethink the Models}

A Case for Reindustrialization? In the United Kingdom, while the number of companies manufacturing outside the UK increased from 32\% to $42 \%$ between 2009 and 2012, a survey by the EEF [18] showed that $40 \%$ of manufacturers have brought a part of their manufacturing capacities back from overseas. For these companies who still need to be competitive on price, the cost conceptual model has changed: "UK manufacturers are increasingly securing orders based on quality, service and providing complete solutions". More than half of UK manufacturers expect to increase domestic sourcing over the next few years [19]. The balance between trying to enhance the part of the value chain offshored, integrating the costs of managing uncertainty, quality, logistics, production and suppliers, spread all over the world, plus the wage inflation in some emerging markets are adding up to the Total Costs. Strategic thinking can then add more value by having both suppliers and customers nearby: this gives an advantage in term of reactivity, building supplier relationships beyond transactional, to a collaborative relationships on new products and processes, and a visibility on their financial health.

This is not just about UK. Many OECD countries are thinking alike. The United States for example are on the same reevaluation process: the reshoring idea is at the heart of a program from the Obama Administration initiated in June 2011 called Advanced Manufacturing Program [20] to recreate hi-tech manufacturing base to create jobs for American workers and reduce trade deficit, and the trend is on with the president's FY 2013 budget with a strong focus on strengthening advanced manufacturing capabilities. Harry Moser who created a non-profit program called the Reshoring Initiative, declares [21]: "The goal is to balance the U.S. trade deficit, which is $\$ 600$ billion a year. That is largely due to offshoring of manufacturing jobs. Since the 1950s, about three million manufacturing jobs have been lost to imported goods. So to balance the deficit we'll need to bring back three million jobs." Harry Moser states that in the U.S. 61 percent of larger companies surveyed "are considering bringing manufacturing back to the U.S.".

Industrial Decline and Linear Model. Since the first and the second industrial revolutions, the industrial model and the business models associated with it has been based on a linear flow: raw materials extraction and transformation, use and waste. Though older economies were taking into account reuse or regeneration models, "consumer goods society" has been largely adopted worldwide and a form of prosperity seems to have been achieved for developed nations. But the "nature and causes of the wealth of nations" [22] seems to become the nature and cause of doom time for human kind. 
First, we are already experiencing the "limits to growth" [23] predicted back in 1972. Developed and emerging markets for consumer goods is estimated [1] around USD 12 trillion in 2012 while tapping into non renewable and finite resources for about USD 3 trillions [1] and producing about $75 \%$ of municipal solid waste [1][24]. Second, while the physical and environmental limits and issues are already here, the demand is growing with an estimated middle class to boom from 1.9 billion in 2009 to 4.9 in 2030 according to OECD [25].

Pushed by the competitive cost models we've examined previously, the paradigm of linear economy is based on globally spread actors along value chains, going from raw sourcing and chemicals inputs, globally spread manufacturing processes, global distribution and retail channels to reach consumers that trash products that are, for the best, ending in landfills or being incinerated. This globalized flow relies on intensive energy consumption of fossil fuels. The underlying economic model for each economic actor is competition based on costs and differentiation [6][9], each of them needing to maintain the growth of large volume of the flow, short products lifespan and complex heavy packaging to either meet global transportations requirements for conservation or for simple marketing differentiation.

Consumers are globally spread just like are different economic agents, located according the markets to be addressed and the cost model of agents building models to reduce labor cost by compensating with resource and energy intensity. Cheap non renewable fossil fuels have been the engine of the economic growth [26] with growing transport flows of materials and goods, allowing offshoring of production for consumption to lower costs regions where fiscal and legal regimes left negative externalities easily uncounted, while cheap energy and resources allowed agents to focus on margin and shareholder return on investments.

This actual mismanagement of resources in the linear economy carry vast amounts of value destruction: spillage and degradations all along the value chain of agroindustries, value lost in design and processing, value lost in distribution, use and end of life [1]. All the value lost in spillage adds up to the rising health, environmental and economic costs of disposals. When unmanaged, spillage and waste ends-up in nature, destroying environmental ecosystems, reducing furthermore the "ecosystem services" [27] and ultimately, just like plastic in the Pacific Garbage Patch, affects our own food chain. Environmental risks and their costs can be evaluated, but the intrinsic uncertainties of the consequences in the long run they could cost are not [28] so perhaps it's about time to redesign the models.

Beyond the environmental impacts [29] this vast amounts of resources spillage started to become really visible and in fact turned into a heavy burden when rising prices and volatility on commodity ( $150 \%$ from 2002 to 2010), fossil fuels and agricultural prices revealed the weaknesses of the model. These new risks are putting a high pressure on companies that were not prepared to confront the meeting of limited resource and growing consumption, and in an interconnected world, all issues are related [3].

Closing the Loop. A rapid review on circular economy shows there is limited research literature on this topic for global systems, but rather in the evaluation of ecoindustrial parks [30][31]. The models have to be studied on a more global scale and cases studies need to be compiled. New business models are emerging from real life economy and adaptive capacities of a limited part of the players. There is paradigm 
shift that needs to be taken and both academic institutions, and economic schools need to experiment new models that are currently out of their scope, even when multinational companies are leading the experiments.

\section{Towards Circular Economy}

As we've seen, the actual linear economy cannot be sustainable and is widely based on reducing responsibility of agents to the minimal requirements imposed by the market and the legal environment. Given the figures of consumption growth, it's self evident that making processes more efficient, even recycling up to $50 \%$ of the metals we use for example, by the actual growth, will not change the scarcity of these resources on the market [32], we would just delay the problems.

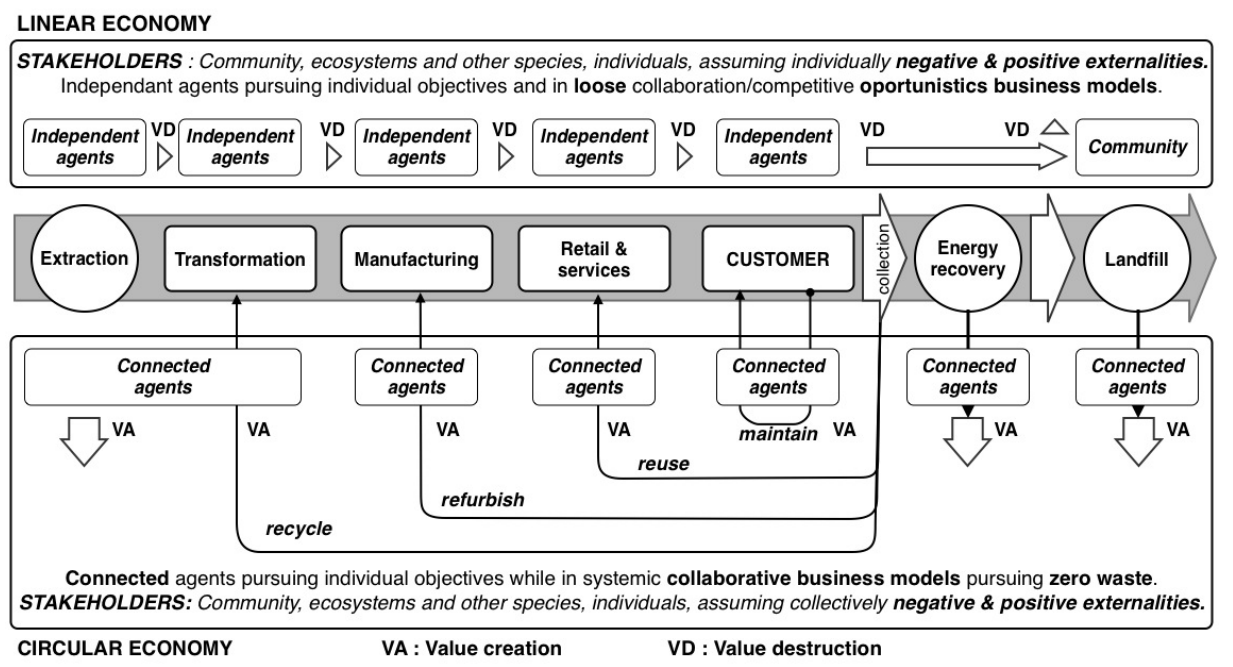

Fig. 4. Value in linear economy and circular economy, adapted from EllenMac Arthur TCE

Moreover, very efficient systems are fragile in essence [33] as they are built with fewer nodes and connections. To build an industrial circular economy, there is a necessary paradigm shift: "Circular economy changes the traditional one-way linear economic model of "resource - product - waste" with value destruction at each step (noted VD in figure 4), into feedback circular economy mode of "resource - product waste - renewable resource", which conforms to the concept of sustainable development, utilizes resource and protects environment more effectively so as to gain maximal economic and social benefits with minimal resource consumption and environment cost." [31]

Collaboration at the Heart of the Model. Circular economy requires also to change the approach to a view by flows that are of two types [34]: The flow of materials that can re-enter into the biosphere without harming it and even rebuilding it, and the flow of technical materials that cannot re-enter the biosphere and need to be "designed to 
be recovered, refreshed and upgraded, minimizing the energy input required and maximizing the retention of value" [1].

Circular economy also builds on "functional service" models where the value is not created by the consumption or the possession of products, but by their use and the services they provide [35]. Most of all, it requires to think industry development reusing principles found in nature: systems where agents are connected, pursuing individual or collective objectives but in systemic collaborative business models pursuing zero waste. This requires interdependency and constant feedback, that is actual collaborative models, extracting value in a cascade of transformation through other applications (noted VA in figure 4), for example by converting waste into byproducts, design multicriteria models and with a definitive shift to renewable energy.

\section{Conclusion}

Energy prices, commodity prices volatility, agriculture and food prices, natural catastrophes are exposing every region and every economic agent worldwide by ripple effects. Our specialization models and dependence on globalized infrastructure and markets are threatening all systems [3]. For companies this implies redesign of business models, integrating end of life products by design collection and reverse logistics. Increasing circularity of flows from cradle to cradle, reducing energy intensity and create most value of by-products requires rebuilding local networks of partners and industries: ecosystems. As stated in the Ellen MacArthur report "Towards Circular Economy"[1]: "Closing the loop' in the circular economy essentially requires much closer and more extended collaboration between participants. (...) A circular economy could cut net materials costs and reduce price volatility and supply risks. Local job creation will be another important benefit, alongside greater innovation and greater resilience". What else do we need?

Acknowledgements. This paper is part of the PEAK research program (Purchasing European Alliance For Knowledge).

\section{References}

1. The Ellen MacArthur Foundation. Towards the circular economy 112 (2013)

2. World Commission on Environment and Development. Our common future. Oxford University Press (1987)

3. Howell, W.L.: Risk Response Network. Global risks 2013. World Economic Forum (2013)

4. Porter, M.E., Kramer, M.R.: Creating Shared Value. Harvard Business Review (2011)

5. Porter, M.E., Rivkin, J.W.: Prosperity at risk. Findings of Harvard Business School's Survey on U.S. Competitiveness (2012)

6. Porter, M.E.: Competitive strategy: techniques for analyzing industries and competitors, c1980. Free Press, Originally published (1998)

7. Poissonnier, H., Philippart, M., Kourim, N.: Les achats collaboratifs: pourquoi et comment collaborer avec vos fournisseurs. De Boeck (2012)

8. Porter, M.E.: Competitive advantage: creating and sustaining superior performance: with a new introduction, c1985. Free Press, Originally Published (1998) 
9. Kraljic, P.: Purchasing must become supply management. Harvard Business Review 61, 109-117 (1983)

10. Carroll, A.B.: A Three-Dimensional Conceptual Model of Corporate Performance. Academy of Management Review 4, 497-505 (1979)

11. Johnson, H.L.: A Berkeley View of Business and Society. California Management Review 16, 95-100 (1973)

12. Freeman, R.E.: Strategic management: a stakeholder approach. Pitman (1984)

13. Aupperle, K.E., Carroll, A.B., Hatfield, J.D.: An Empirical Examination of the Relationship Between Corporate Social Responsibility and Profitability. Academy of Management Journal 28, 446-463 (1985)

14. Wartick, S.L., Cochran, P.L.: The Evolution of the Corporate Social Performance Model. Academy of Management Review 10, 758-769 (1985)

15. Oshri, I., Kotlarsky, J., Willcocks, P.L.P.: The Handbook of Global Outsourcing and Offshoring. Palgrave Macmillan (2011)

16. Jacquemin, A.: Le phénomène de désindustrialisation et la Communauté Européenne. Reco 30, 985-999 (1979)

17. Bettis, R.A., Bradley, S.P., Hamel, G.: Outsourcing and industrial decline. Executive (19389779) 6, 7-22 (1992)

18. Hopley, L.: EEF Economics Blog I Reshoring - is it real? eef. The Manufacterers' Organisation (2013),

http: / /www. eef .org.uk/blog/post/Reshoring-is-it-real.aspx

19. EUI. Global Manufacturing Outlook: Fostering Growth through Innovation (2012)

20. IEEE-USA, http: / / www . todaysengineer.org/2013/Jan/reshoring . asp

21. MIT Technology Review. The Next Wave of Manufacturing (2013)

22. Smith, A.: An inquiry into the nature and causes of the wealth of nations: a selected edition. Oxford University Press (1998)

23. Meadows, D.H., Rome, C., Associates, P.: The Limits to growth: a report for the Club of Rome's project on the predicament of mankind. Universe Books (1972)

24. US EPA, http: / /www. epa.gov/epawaste/nonhaz/municipal/msw99.htm

25. Organisation for Economic Co-operation and Development \& OECD iLibrary. Perspectives on global development 2012: social cohesion in a shifting world. OECD (2011)

26. Dobbs, R., Oppenheim, J., Thompson, F., Brinkman, M., Zornes, M.: Resource revolution: Meeting the world's energy, materials, food, and water needs. McKinsey Global Institute (2011)

27. Costanza, R., et al.: The value of the world's ecosystem services and natural capital. Ecological Economics 25, 3 (1998)

28. Éloi, L.: Economie de l'environnement et économie écologique. Armand Colin Editions (2012)

29. Millennium Ecosystem Assessment (Program). Ecosystems and human well-being: current state and trends: findings of the Condition and Trends Working Group of the Millennium Ecosystem Assessment. Island Press (2005)

30. Wenbo, L.: Comprehensive evaluation research on circular economic performance of ecoindustrial parks. Energy Procedia 5, 1682-1688 (2011)

31. Ying, J., Li-jun, Z.: Study on Green Supply Chain Management Based on Circular Economy. Physics Procedia 25, 1682-1688 (2012)

32. Raisson, V.: atlas des futurs du monde: 2010...2033. Laffont (2010)

33. Taleb, N.: Anti-fragile: how to live in a world we don't understand. Allen Lane (2012)

34. McDonough, W.: Cradle to cradle: remaking the way we make things. North Point Press (2002)

35. Kazazian, T.: Il y aura l'âge des choses légères: design et développement durable. Victoires-Editions (2003) 